\title{
Some investigations on incidence and infestation level in Cyprinid postodiplostomosis
}

\author{
Octavian NEGREA ${ }^{1)}$, Vioara MIREŞAN ${ }^{1}$, Camelia RĂDUCU ${ }^{11}$, Grigore ONACIU ${ }^{11}$, \\ Octavia NEGREA $^{1)}$, Călin LAŢIU ${ }^{11}$, Daniel COCAN ${ }^{1)^{*}}$ \\ ${ }^{1}$ University of Agricultural Sciences and Veterinary Medicine Cluj-Napoca, Faculty of Animal Science \\ and Biotechnologies Cluj-Napoca, 3-5 Mănăştur Street, 400372, Romania \\ *Corresponding author, e-mail: cocandaniel@yahoo.com
}

Bulletin UASVM Animal Science and Biotechnologies 72(2) / 2015

Print ISSN 1843-5262; Electronic ISSN 1843-536X

DOI:10.15835/buasvmcn-asb:11457

\begin{abstract}
In our study, we sampled 82 fish specimens as follows: 62 rudd (Scardinius erythrophthalmus), 8 roach (Rutilus rutilus) and 12 silver bream (Blicca bjoerkna). The sampling was done in Țaga Mare Lake, Cluj County. The investigations took into account the incidence and infestation levels of fish with Posthodiplostomum cuticola metacercaria. The study results show an incidence of parasitosis of $80.60 \%$ for rudd, $75.00 \%$ for roach and $25.05 \%$ for silver bream. Regarding the intensity of infestation (low, medium and high), low levels of infestation are predominant (rudd $72 \%$; roach $83.30 \%$; silver bream $-66.60 \%$ ). The preferred body area for metacercaria (in descending order) are as follows: for rudd $-90.00 \%$ on the body, 86.00 on the fins and caudal peduncle, and $28.80 \%$ on the head; for roach $-50.00 \%$ on the body, $66.00 \%$ on the fins and caudal peduncle, and $33.00 \%$ on the head; for silver bream $-100.00 \%$ on the body, $33.00 \%$ on the fins and caudal peduncle, and $33.00 \%$ on the head.

Histopathological sections were taken from musculocutaneous tissue extracted from the dorsal area of fish which was parasitized with cystic metacercariae. The central points of metacercaria is surrounded by a connective structure in the form of a capsule, in which melanocyte-like cells are predominant. Intracytoplasmically, they show a brown-blackish granular pigment which masks the cell nucleus. Perifocally, the inflammatory cell infiltrate is discreet with few mononuclear heterophile cells.
\end{abstract}

Keywords: postodiplostomosis, metacercariae, infestation.

\section{INTRODUCTION}

Postodiplostomosis, popularly known as the "ink spot disease" is a parasitic disease of freshwater and marine fish (Constantin and Oţel, 1989; Munteanu and Bogatu, 2003). This disease is caused by the metacercaria of some trematodosis species (Negrea, 2007). These species (adult status) are found in the intestine of birds that eat fish (definitive hosts), and the larval forms parasitize different species of aquatic gastropods (intermediate hosts). Fish eat these aquatic gastropods, and trematodesis transformed into cysts. These cysts are located in the musculocutaneous tissue of different cyprinidae fish species or marine fish species. These cysts then form encapsulates and, appear as perifocal nodules bounded by a ring of melanin, with blackish colour on the skin and fins of fish (Paperna and Dzikowski, 2006). These rings with melanin aspect give the name of "ink spot disease". This disease is very dangerous for the fish fry in the first months of life (Ondrackova et al., 2004; Zrncic et al., 2009). At this stage, mortality losses may reach $100 \%$. Nonetheless, the parasitic effect is reduced in the adult fish, but the implications are aesthetic and economic. The presence of these nodular formations with blackish colour decreases the commercial value of fish.

The aim of our study was to evaluate the Posthodiplostomum cuticola level of infestation of some cyprinidae species from Țaga Mare Lake. For this, we proposed to take histopathological 
sections from the fish body areas in which the metacercaria were present and to assess them in terms of the incidence of infestation.

\section{MATERIALS AND METHODS}

The research regarding the incidence and intensity level of postodiplostomosis in some cyprinid fish was carried out in May 2015. Fish were caught by angling from Țaga Mare Lake (Fizeș Valley), Cluj County. We sampled 82 fish specimens, as follows: 62 rudd (Scardinius erythrophthalmus), 8 roach (Rutilus rutilus) and 12 silver bream (Blicca bjoerkna). A macroscopic clinical examination was carried out to detect fish samples affected by postodiplostomosis "ink spot disease". The level of infestation was quantified as follows: massive infestations (over 10 nodules), medium infestations (5-10 nodules) and low infestations (1-5 nodules). Simultaneously, we observed their body location in the affected fish (head, trunk and other areas), and also quantified the intensity of parasitism by counting "black spots". After sampling nodules from fish contaminated with parasites (squash technique), metacercaria were identified by microscopy (Fig. 1). The musculocutaneous tissue samples were stained with hematoxylin-eosin for histopathological examination.

\section{RESULTS AND DISCUSSION}

Investigation conducted on 82 cyprinid fish species (62 rudd-; 8 roach; 12 silver bream) regarding the incidence and intensity of parasitism with Posthodiplostomum cuticola highlight the following values, which are presented in table 1.

The obtained data show a high level of parasites in rudd - 80.65\% (50 fish), but with different levels of intensity of parasitism. Low infestation is predominant $(72.00 \%-36$ fish), followed by medium infestations $(22.00 \%-11$ fish $)$ and high infestation $(6.00 \%$ - 3 fish).

Tab. 1. The value of the incidence and intensity of parasitosis with Posthodiplostomum cuticola, in the studied fish species

\begin{tabular}{|c|c|c|c|c|c|c|c|c|c|}
\hline \multirow{2}{*}{ Fish Species } & \multirow[t]{2}{*}{$\mathrm{n}$} & \multirow{2}{*}{$\begin{array}{l}\text { Positive } \\
\text { Samples }\end{array}$} & \multirow[t]{2}{*}{$\%$} & \multicolumn{2}{|c|}{$\begin{array}{l}\text { High Incidence } \\
\text { Level }\end{array}$} & \multicolumn{2}{|c|}{$\begin{array}{l}\text { Medium Incidence } \\
\underline{\text { Level }}\end{array}$} & \multicolumn{2}{|c|}{$\begin{array}{l}\text { Low Incidence } \\
\text { Level }\end{array}$} \\
\hline & & & & $\mathrm{n}$ & $\%$ & $\mathrm{n}$ & $\%$ & $\mathrm{n}$ & $\%$ \\
\hline $\begin{array}{l}\text { Rudd } \\
\text { (Scardinius erythrophthalmus) }\end{array}$ & 62 & 50 & 80.65 & 3 & 6.00 & 11 & 22.00 & 36 & 72.00 \\
\hline $\begin{array}{c}\text { Roach } \\
\text { (Rutilus rutilus) }\end{array}$ & 8 & 6 & 75.00 & - & - & 1 & 16.60 & 5 & 83.40 \\
\hline $\begin{array}{c}\text { Silver bream } \\
\text { (Blicca bjoerkna) }\end{array}$ & 12 & 3 & 25.00 & - & - & 1 & 33.40 & 2 & 66.60 \\
\hline
\end{tabular}
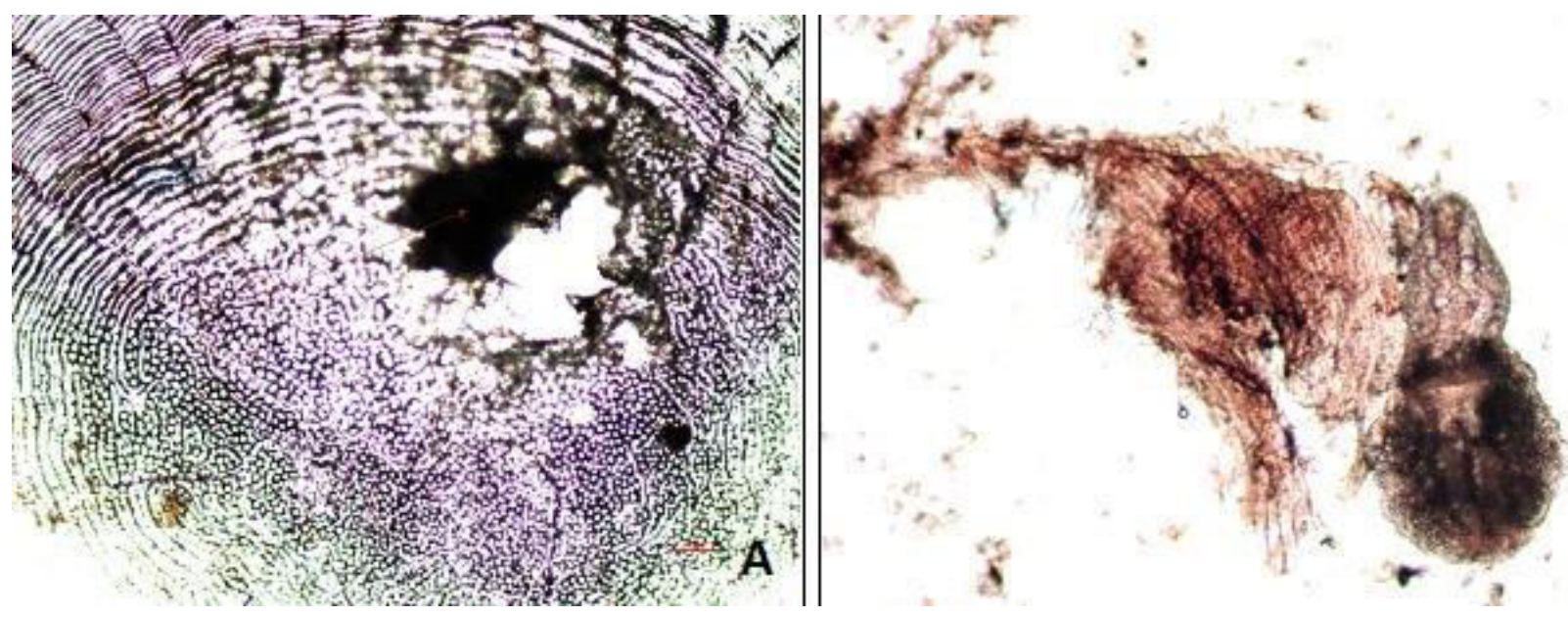

Fig. 1. Posthodiplostomum cuticola metacercaria located on rudd scales (A); Metacercaria - a microscope image (B) 
The level of infestation with Posthodiplostomum cuticola for roach is as follows: positive samples $75.00 \%$ (6 fish), low infestation (83.40\% - 5 fish), and medium infestation (16.60\% - 1 fish). At this species high infestation has not been seen.

From the obtained data it results that the incidence of parasites in silver bream is at a low level compared with the other 2 cyprinid species (rudd and roach). The positive samples for this species were $3(25.00 \%)$ and the infestation level was as follows: low infestation (66.60\% - 2 fish) and medium infestation (33.40\% - 1 fish). Similar to roach, high infestation has not been seen in silver bream either.

Figure 2 presents some examples of Posthodiplostomum cuticola metacercaria positioning. As seen, in the case of rudd, they are located in particular at the level of the body. In roach, the metacercaria are located mainly on the caudal peduncle and on the opercular apparatus. At the silver bream, metacercaria are located on the opercular apparatus and fins.
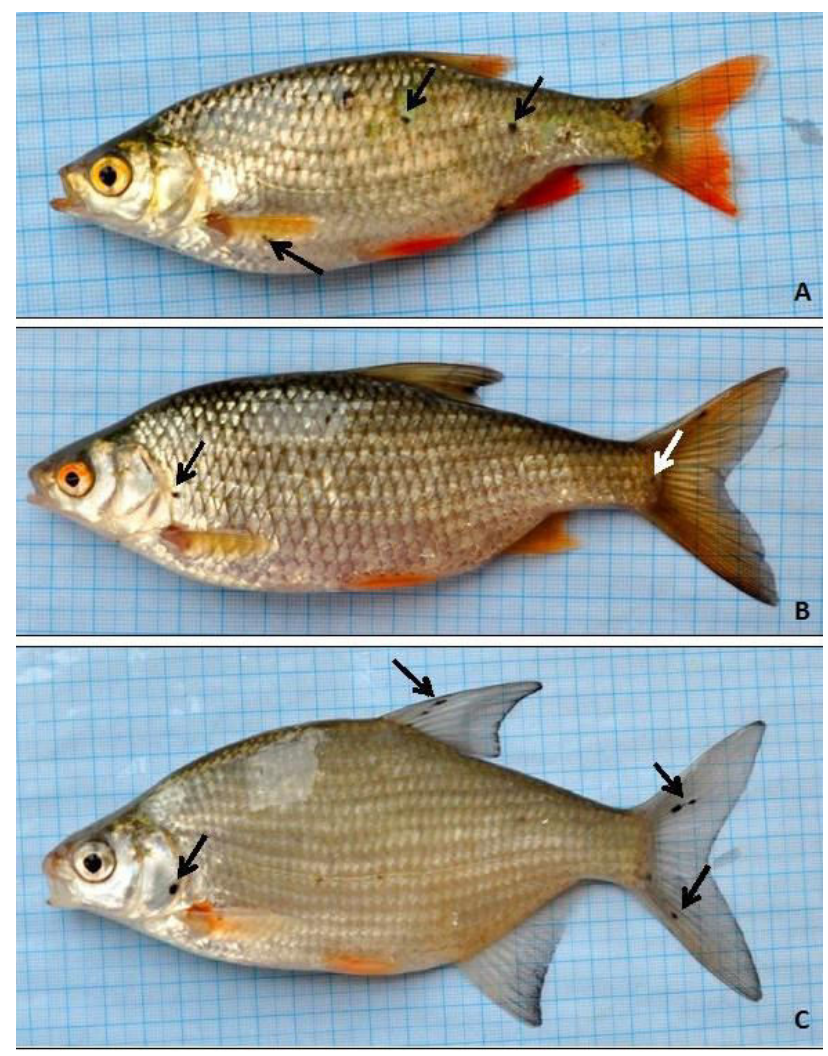

Fig. 2. Distribution of Posthodiplostomum cuticola metacercaria on the fish body:

A-rudd (Scardinius erythrophthalmus); B-roach (Rutilus rutilus); C-silver bream (Blicca bjoerkna)
The incidence and the intensity of parasitism with Posthodiplostomum cuticola metacercariae on the studied cyprinid fish are presented in figures 3, 4 and 5 .

Our data regarding the favourite areas for metacercaria on the fish body highlight differences among the examined species. Thus,

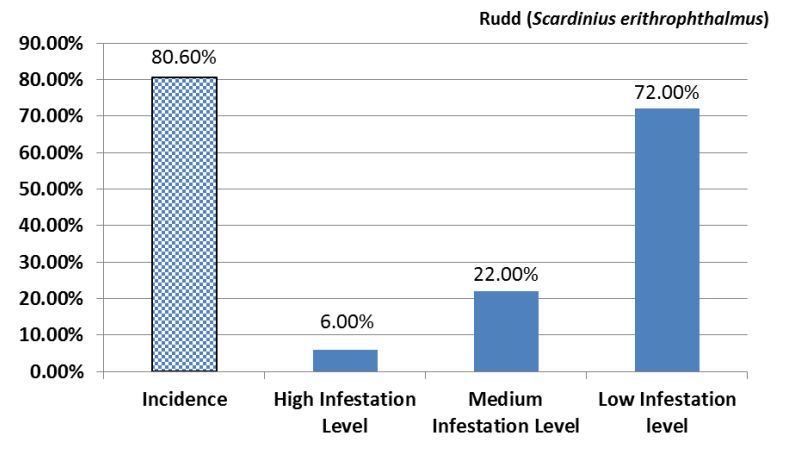

Fig. 3. The incidence and intensity of parasitism with Posthodiplostomum cuticola metacercaria in rudd (Scardinius erythrophthalmus)

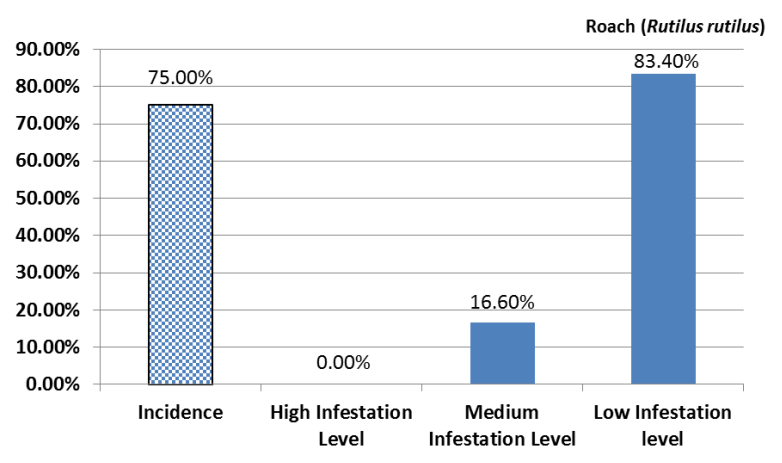

Fig. 4. The incidence and intensity of parasitism with Posthodiplostomum cuticola metacercaria in roach (Rutilus rutilus)

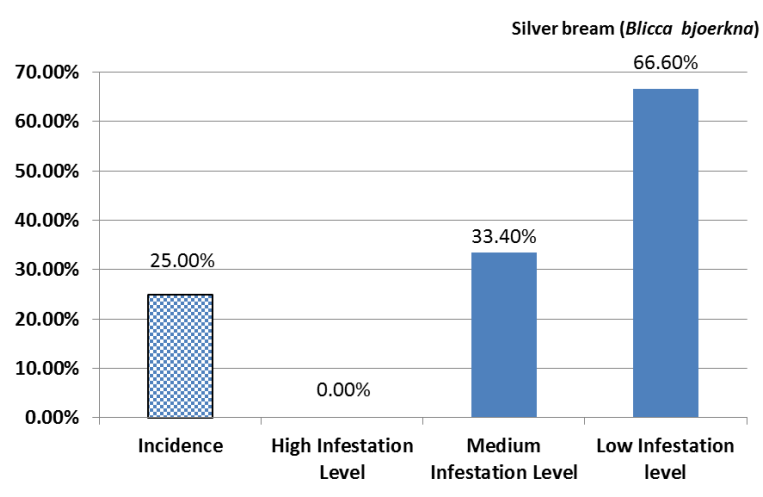

Fig. 5. The incidence and intensity of parasitism with Posthodiplostomum cuticola metacercaria in silver bream (Blicca bjoerkna) 
in the case of rudd, the maximum intensity of the location level is on the body (90.00\%), followed by the other areas (fins and caudal peduncle $86.00 \%$; head $-28.00 \%$ ). In contrast, in roach the dominant locations of Posthodiplostomum cuticola metacercaria is on the fins $(66.60 \%)$, followed by the body (50.00\%) and the head (33.30\%). In silver bream, high density of black spots is found on the fins $(100.00 \%)$ followed by other areas (66.60\%).

The histopathological section, processed with the special histopathology technique, shows the presence of metacercaria in the central area of the cyst. The cyst is located deep in the muscle tissue and it is surrounded by a connective tissue. This results in an aspect similar to a capsule in which numerous types of melanocyte cells (melanocytes and/or melanophages) are highlighted. These cells have a dark brown pigment in the cytoplasm and a granular aspect masking the nucleus. On the periphery, slightly discreet, there is a cell infiltrate with few mononuclear and some heterophile cells.

\section{CONCLUSIONS}

Our research on the incidence and intensity of parasitism in postodiplostomosis highlights the following:

1. The incidence of parasitosis presents high values in rudd $(80.60 \%)$, followed by roach $(75.00 \%)$ and silver bream $(25.00 \%)$.

2. In most cases we identified a low level of infestation (rudd - 72.00\%; roach - 83.30\%; silver bream $66.60 \%$ ).

3. Body areas in which metacercaria (cyst form) were located are as follows, in descending order: rudd $-90.00 \%$ on the body, $86.00 \%$ on fins and caudal peduncle, $28.00 \%$ on the head; roach $-50.00 \%$ on the body, $66.00 \%$ on the fins and caudal peduncle and $33.00 \%$ on the head; silver bream $-100.00 \%$ on fins and $66.00 \%$ on other areas (head, caudal peduncle and body).

4. The histopathological section shows the presence of metacercaria in the central area of cyst.

5. This cyst is located deep in the muscle tissue and it is bordered by a connective tissue.

6. The border of the cyst confers it a capsule-like aspect in which numerous types of melanocyte cells (melanocytes and/or melanophages) are highlighted.

7. On the periphery, there is a cell infiltrate with few mononuclear and some heterophile cells.

\section{REFERENCES}

8. Bruno D, Noguera PA, Poppe TT. (1997). A Colour Atlas of Salmonid Diseases, SecondEdition, Springer, Abeerden, New York.

9. Constantin G, Oțel V. (1989). Ghid Ihtiopatologic pentru piscicultura din Delta Dunării, Buletinul de Cercetări Piscicole, Suplimentul II.

10. Munteanu G, Bogatu DI. (2003). Tratatul de ihtiopatologie, Editura Excelsior Art, Timişoara, pag.416-424.

11. Negrea O. (2007). Bolile peştilor, Editura Academic Press, Cluj-Napoca.

12. Ondrackova M., Reichard M, Jurajda P, Gelnar M. (2004). Seasonal dynamics of Phostodiplostomum cuticola (Digenea, Diplostomatidae) metacercariae and parasiteenhanced growth of juvenile host fish. Parasitol Res., 93: 131-136.

13. Paperna I, Dzikowski R. (2006). Fish Diseases and disordes Vol.I: Protozoan and Metazoan Infections, second edition, P.T.K. Woo, Univ.Of Guelph, Canada.

14. Zrncic S., Oraic D., Mihaljevic Z., Caleta M., Zanella D., Jelic D., Jelic M., (2009). First observation of Postodiplostomum cuticola (Nordmann, 1832) metacercariae in cypriniformes from Croatia. Helmithologia, 46 (2): 112116.

15. www.histopatology-india.net

16. www.phys.org

17. www.wikipedia.org 